\title{
Determinants of long-term home nursing care among people over 65 years of age
}

\section{Determinanty długoterminowej domowej opieki pielęgniarskiej wśród osób po 65. roku życia zamieszkałych w środowisku wiejskim}

\author{
Małgorzata Dziechciaż¹, Izabela M. Wróblewska², Jarosław Chmielewski³ ${ }^{3}$ Edyta Guty¹, Luiza Balicka-Adamik \\ Rafał Filip ${ }^{4}$, Monika Szpringer ${ }^{5}$ \\ ${ }^{1}$ Department of Health Sciences, Health Care Institute, State School of Higher Vocational and Economic Education, Jarosław, Poland \\ Head of the Department: Prof. Janusz Schabowski MD, PhD \\ ${ }^{2}$ Department of Gerontology, Faculty of Health Sciences, Medical University of Wroclaw, Poland \\ Head of the Department: Prof. Jarosław Drobnik MD, PhD \\ ${ }^{3}$ Institute of Environmental Protection, National Research Institute, Warsaw, Poland \\ Head of the Institute: Krystian Szczepański PhD \\ ${ }^{4}$ Department of Gastroenterology, Clinical Regional Hospital No. 2 Św. Jadwigi Królowej, Faculty of Medicine, Rzeszow University, \\ Rzeszow, Poland \\ Head of the Department: Prof. UR Rafał Filip MD, PhD \\ ${ }^{5}$ Department of Social Prevention, Faculty of Medicine and Health Sciences, Jan Kochanowski University, Kielce, Poland \\ Head of the Department: Prof. JKU Monika Szpringer MD, PhD
}

Key words: elderly people, long-term care, house care.

Słowa kluczowe: osoby starsze, opieka długoterminowa, opieka domowa.

\begin{abstract}
Introduction: With age comes increasing loss of efficiency, and thereby increasing dependence on others and increasing demand for nursing and care services

Aim of the research: To determine the factors of demand for long-term home nursing care among people over 65 years old. Material and methods: The research was conducted on 504 subjects aged between 66 and 94 years. The qualified respondents for the long-term home-based nursing care scored no more than 40 points in Barthel's Index. The following research tools were used: Barhel's Index, IADL, GDS, AMTS, and an authorial interview questionnaire.

Results: For long-term home-based nursing care $15.67 \%(n=79)$ of subjects were qualified; there were more women $(n=61)$ than men $(n=18)(p<0.05)$. The age of respondents qualified for long-term nursing care was higher than the age of other test subjects $(p<0.001)$. Among subjects qualified for long-term home-based nursing care there were more people with incomplete primary education $(p<0.01)$ and a higher number of multi-diseases than with the rest $(p<0.01)$. Moreover, people qualified for long-term nursing care had worsened agility to perform complex life activities and worsened cognitive and emotional performance $(p<0.001)$ than people who did not qualify for such services.

Conclusions: The need for long-term nursing care was determined by progressing ageing, functional, emotional, and cognitive disorders, more frequent with women, people with low education, and multi-diseases.
\end{abstract}

\section{Streszczenie}

Wprowadzenie: $Z$ wiekiem postępuje utrata sprawności, a także zwiększa się uzależnienie od innych osób i zapotrzebowanie na świadczenia pielęgnacyjne i opiekuńcze.

Cel pracy: Określenie czynników determinujących zapotrzebowanie na długoterminową domową opiekę pielęgniarską u osób po 65. roku życia zamieszkujących na wsi.

Materiał i metody: Badaniami objęto 504 osoby w wieku 66-94 lat. Do długoterminowej domowej opieki pielegnniarskiej zakwalifikowano respondentów, którzy w skali Barthel uzyskali nie więcej niż 40 pkt. W pracy zastosowano takie narzędzia badawcze, jak skala Barthel, IADL, GDS, AMTS oraz autorski kwestionariusz wywiadu.

Wyniki: Do długoterminowej domowej opieki pielęgniarskiej zakwalifikowano 15,67\% $(n=79)$ badanych, więcej kobiet $(n=61)$ niż mężczyzn $(n=18)(p<0,05)$. Wiek respondentów zakwalifikowanych do długoterminowej opieki pielęgniarskiej był wyższy od wieku pozostałych badanych $(p<0,001)$. Wśród osób zakwalifikowanych do długoterminowej domowej opieki pielęgniarskiej było więcej osób z wykształceniem niepełnym podstawowym $(p<0,01)$ oraz z większą liczbą jed- 
nostek chorobowych niż u pozostałych badanych $(p<0,01)$. Ponadto osoby zakwalifikowane do długoterminowej opieki pielęgniarskiej cechowały się gorszą sprawnością w wykonywaniu złożonych czynności życiowych oraz gorszą sprawnością poznawczą i emocjonalną $(p<0,001)$ niż osoby niezakwalifikowane do tego rodzaju świadczeń.

Wnioski: Zapotrzebowanie na pielęgniarską opiekę długoterminową było determinowane starszym wiekiem, niesprawnością funkcjonalną, emocjonalną i poznawczą oraz częściej dotyczyło kobiet, osób z niższym wykształceniem i z większą liczbą chorób.

\section{Introduction}

The systematic increase in the number of older people in society poses new challenges for the health care system. With age, the loss of efficiency increases, and thereby dependence on others and demand for nursing and care services grows [1].

According to the European Commission's assessment, $5 \%$ of people over 65 years old are completely dependent and 15\% partially dependent on long-term care. This percentage increases with age, at the age of 75 years $15 \%$ patients need constant care, and partial care $25 \%$ of the population [2]. Demographic projections indicate that the number of seniors who need long-term care will increase to four million by 2030 [3]

In Poland, long-term care provided by nurses in the patient's home has been functioning since 2004 . Initially it was under the name of "long-term nursing care" and now as "long-term home nursing care" [4]. Long-term home nursing care is a part of the guaranteed benefits in the field of nursing and care services in the context of long-term care. According to the decree of the President of the National Health Fund, "it is care for chronically ill patients staying at home, who do not require hospitalisation for stationary treatment, and due to existing health problems require regular nursing care provided in their home" [5].

Benefits under this care can be provided by the nurse has completed a specialisation or qualification course in the field of long-term care or nursing for: the chronically ill and the disabled; family; preventive; environmental; environmental/family; children; geriatric; or palliative care as well as someone who has completed a specialist course in palliative care or is currently attending the course and specialisation.

Long-term home care nurses provide services based on referral from a health insurance physician to the somatically, psychosomatically, and mentally sick with the exception of the acute phase of mental illness that, assessed by the Barthel scale, received no more than 40 points. In addition, these people cannot be provided for by home hospice services, a stationary care facility, or by a team giving long-term home care for adults, children, and adolescents who are mechanically ventilated.

The duties of long-term home nursing care are: - preparation of the patient and his/her family to self-care and also in his/her ability to cope with disability,

- providing care services in accordance with the nursing process,
- conducting health education of both the patient and his/her family,

- assistance in solving the health problems associated with an independent functioning in the domestic environment,

- assistance in obtaining medical and rehabilitation equipment necessary for the proper care and rehabilitation of the patient at home [6].

Nursing services should be comprehensive and should complement other forms of health services because professional long-term care significantly improves the lives of patients [7, 8].

According to Kulik a house for an elderly person, especially when chronically ill, is a natural place to stay where his/her care can best be organised [9]. Therefore, access to long-term nursing care in the patient's home should become a priority in the care of chronically ill and functionally disabled seniors, for both economic and psychological reasons [10].

\section{Aim of the research}

The aim of this study was to identify factors of demand for long-term home nursing care among people over 65 years of age in rural areas.

\section{Material and methods}

The research was carried out by a diagnostic survey. The technique of direct interview was used, as well as research tools such as: the Barthel Index for the assessment of vital signs; the Instrumental Activities of Daily Living (IADL scale) to evaluate complex life activities; Abbreviated Mental Test Score (AMTS) to assess cognitive performance, Geriatric Depression Scale (GDS) to assess the prevalence of depression and the Author's questionnaire for the assessment of the sociodemographic, financial, health, and social support received. To conduct long-term home nursing care were qualified respondents who in the Barthel Index gained 40 points or less and did not benefit from a hospice care home or group long-term home care for adults, children, and adolescents, who were mechanically ventilated.

The study involved 504 people aged from 66 to 94 years residing in rural areas of Southeastern Poland.

\section{Statistical analysis}

To study the relationship between selected variables the following statistical tests were used: Kendall's tau test, Kolmogorov-Smirnov test, chi-square 
test $\left(\chi^{2}\right)$ Pearson, Kruskal-Wallis test, and Dunn's post hoc test. All statistical calculations were performed using the statistical package Statistica 6.0 GB.

\section{Results}

The average age of respondents was $77.41 \pm 6.60$ years $(\mathrm{Me}=78$ years). In the study group there were more women $(329 ; 65.28 \%)$ than men $(175 ; 34.72 \%)$ The average age of women was higher (78.05 \pm 6.50 years; $\mathrm{Me}=78$ years) than the average age of men (76.19 \pm 6.65 years; $\mathrm{Me}=76$ years).

Seventy-nine (15.67\% of all respondents) respondents were classified for long-term home nursing care. Among the patients qualified for long-term nursing care, 43 (54.43\%) benefited from such services during the survey.

People who were not benefiting from long-term nursing care $(N=461)$ were asked about the reasons for not using it. The vast majority of respondents ( $n=409 ; 88.72 \%$ of non-users) replied that "there was no need". Subsequently, 5.86\% $(n=27)$ of respondents did not have knowledge about the functioning of long-term care, and 2.17\% $(n=10)$ answered that they "were waiting in a queue". Moreover, 3.25\% $(n=15)$ of respondents were unable to give reasons for not taking long-term care.

Among the 36 people qualified but not included in long-term home nursing care, the most common $(n=19 ; 52.78 \%)$ indicated reason for not using it was that it was "not needed". Another 8 (22.22\%) respondents were "waiting in line", and 5 (13.89\%) did not know about such care. The remaining 4 (11.11\%) persons indicated "other reasons", and more specifically the lack of consent of the daughters of the family.

Significantly more women qualified for long-term home nursing care $(n=61 ; 18.54 \%$ of all surveyed women) than men $(n=18 ; 10.29 \%$ of all male respondents) $(p<0.05)$.

The age of respondents qualified for long-term home nursing care (average 82.03 years) was significantly higher $(p<0.001)$ than the age of the remaining respondents (76.36 years).

Analysis of the level of education of people meeting criteria for being qualified for long-term home nursing care showed that patients with incomplete primary education dominated among the respondents $(n=54 ; 68.35 \%)$, followed by those with primary $(n=22 ; 27.85 \%)$ and professional $(n=3 ; 3.80 \%)$. Among those qualified for long-term home nursing care there were significantly more people with incomplete primary education $(p<0.01)$ and significantly fewer with vocational education $(p<0.05)$.

Analysis of Kolmogorov-Smirnov test revealed that respondents qualification for long-term nursing care occurred significantly more (an average of 3.71) in those suffering from disease entities than did other respondents $(2.86)(p<0.01)$. Moreover, among those qualifying for long-term home nursing care, substantially more had disease units such as stroke, atherosclerosis, Alzheimer's disease $(p<0.001)$, diabetes, and Parkinson's disease $(p<0.05)$ than among those who were not qualified (Table 1).

Table 1. Eligibility to take long-term home nursing care and the occurrence of diseases

\begin{tabular}{|c|c|c|c|c|c|c|c|c|}
\hline \multirow[t]{2}{*}{ Name } & \multicolumn{2}{|c|}{ Total } & \multicolumn{2}{|c|}{ Qualified } & \multicolumn{2}{|c|}{ Not qualified } & \multirow[t]{2}{*}{$\chi^{2}$} & \multirow[t]{2}{*}{$P$-value } \\
\hline & $n$ & $\%$ & $n$ & $\%$ & $n$ & $\%$ & & \\
\hline Hypertension & 391 & 77.58 & 61 & 77.22 & 330 & 77.65 & 0.00 & $>0.10$ \\
\hline Heart failure & 217 & 43.23 & 42 & 53.16 & 175 & 41.18 & 2.38 & $>0.10$ \\
\hline Stroke & 46 & 9.13 & 24 & 30.38 & 22 & 5.18 & 62.85 & $<0.001$ \\
\hline Atherosclerosis & 146 & 28.97 & 35 & 44.30 & 111 & 26.12 & 11.61 & $<0.001$ \\
\hline Asthma & 41 & 8.13 & 5 & 6.33 & 36 & 8.47 & 0.16 & $>0.10$ \\
\hline Diabetes mellitus & 114 & 22.62 & 27 & 34.18 & 87 & 20.47 & 5.51 & $<0.05$ \\
\hline Osteoarthritis & 313 & 62.10 & 47 & 59.49 & 266 & 62.59 & 0.04 & $>0.10$ \\
\hline Parkinson's disease & 9 & 1.79 & 4 & 5.06 & 5 & 1.18 & $4.53^{\star}$ & $<0.05$ \\
\hline Alzheimer & 6 & 1.19 & 4 & 5.06 & 2 & 0.47 & $9.62^{\star}$ & $<0.001$ \\
\hline Neoplasms & 13 & 2.58 & 5 & 6.33 & 8 & 1.88 & $1.74^{\star}$ & $>0.10$ \\
\hline Prostatic hypertrophy & $60^{\star *}$ & 34.29 & 9 & 50.00 & 51 & 32.48 & 2.20 & $>0.10$ \\
\hline Others & 118 & $23.41^{a}$ & $22^{\mathrm{b}}$ & 27.85 & 96 & 22.59 & 0.89 & $>0.10$ \\
\hline
\end{tabular}

* $\chi^{2}$ with Yates correction, ${ }^{* *}$ only men, ${ }^{a}$ in 118 patients were 143 diseases belonging to the category "other", bin 22 respondents diagnosed with the disease were 26 entities belonging to the category "other". 


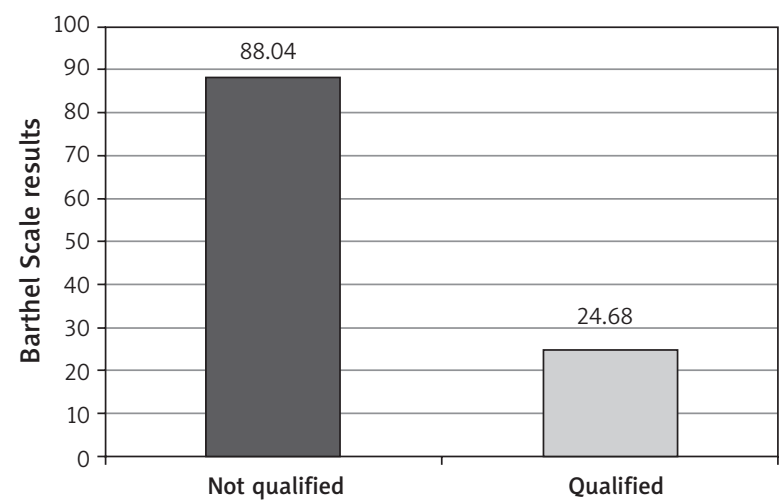

Figure 1. Eligibility to take long-term home nursing care and arithmetic mean of the results on the ATMS $(N=504)$

It was found that in the group of respondents meeting the eligibility criteria to take long-term home nursing care, more were visually impaired $(p<0.01)$ and hearing impaired $(p<0.001)$ than among other respondents.

Respondents fulfilling the criteria to take up longterm nursing care in a home in the assessment of AMTS also achieved significantly lower (5.61) results, demonstrating worse cognitive condition than the subjects not eligible for such benefits (8.07) $(p<0.001)$ (Figure 1$)$.

Persons qualified to long-term nursing care in the GDS assessment received significantly higher (7.94) results, demonstrating worse emotional state than other respondents $(4.40)(p<0.001)$ (Figure 2).

Among the people benefiting from social assistance, qualifying for long-term care nursing, 6 patients (7.59\% qualified for long-term nursing care) benefited from one form of social assistance, and one $(1.27 \%)$ of the two forms. Among the aid received, financial support dominated $(6 ; 7.59 \%)$. With material assistance benefiting two $(2.53 \%)$ respondents.

\section{Discussion}

Long-term nursing care is addressed to chronically ill patients who stay in their own living environment and do not require hospital treatment but due to their problems need intensive nursing care [5].

Long-term nursing care of a disabled person allows them to remain in their natural living environment, reduces the cost of care, and is a source of professional support and assistance for both the caregivers and the patient in the area of health promotion, disease prevention, and care [10].

The benefits carried out in the framework of longterm care, including nursing, are for patients of all ages, but as research shows the most common beneficiaries of such services are seniors [11].

Our own research proved that over $50 \%$ of patients classified for long-term nursing home care have already benefitted from this kind of service. People

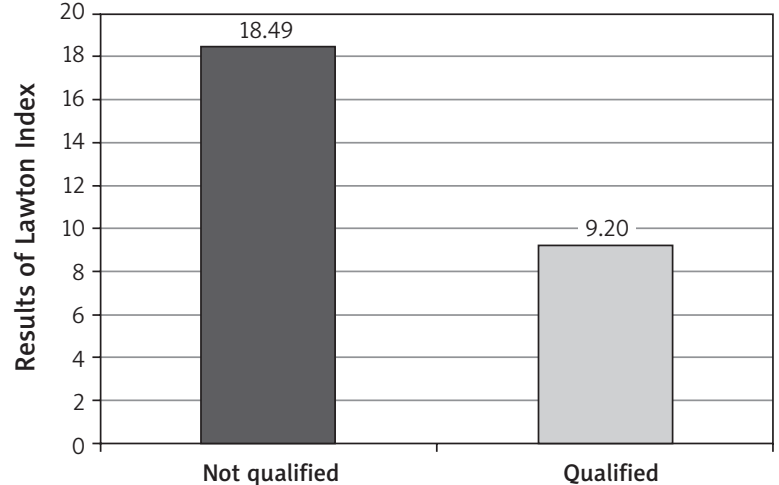

Figure 2. Eligibility to take long-term home nursing care and arithmetic mean of the results on the GDS $(N=495)$

who do not profit from such a form of care gave as the most common reason the fact that they do not need it.

Statistical analysis showed that the age of the respondents classified to take long-term nursing care was higher than the other subjects, and that among people eligible for the care the significant majority were widowed and people with lower education. The study also discovered that people who qualified for long-term home nursing care suffered significantly more from disease, including the most atherosclerosis, diabetes, stroke, Parkinson's disease, and Alzheimer's disease. In addition, it was noted that among the respondents qualified to long-term nursing care functional, cognitive, and emotional disability was more alike.

The fact that only $8.86 \%$ of people eligible for long-term home nursing care received assistance from the social welfare system draws attention, and most of it was financial support. It is interesting that with such a large functional disability, which occurs in people eligible for the care, no one who was under the assistance of social services was not granted the care benefits.

In Polish literature we found only two studies of other authors on the assessment of the need for long-term care. Previous studies of the author and coauthors of the work, carried out among 89 residents of rural areas in Podkarpacie, in the environment of their residence, aged 60 years and older, showed that demand for long-term care occurred in $41.6 \%$ of patients and, as in the present study, it increased with age. It was higher among seniors and those with poorer mental condition, but there were no statistically significant differences between women and men in terms of demand for long-term care [12].

Lewko et al. in a study conducted among patients at the age of 65 years and over in Bialystok's Local Clinic, qualified $37.7 \%$ of women and $35.9 \%$ men for long-term care. The authors confirmed that advancing age is an important factor in the demand for longterm home nursing care [13]. 
The findings of other authors, to which our own research relates, concern nursing care of patients for the long term, which also includes people over 65 years of age. A study by Markiewicz and Cebulak conducted among 190 patients qualified to long-term home nursing care in the Silesian province (in $97.89 \%$ of the population), at the age of 44-100 years (mean age: 81.99 years), showed that long-term home nursing care benefited far more women (77.89\%) than men (22.11\%), and that the dominant level of education was primary education (44.74\%), which may confirm the results presented in this paper. The authors also stated that the average number of points that the respondents obtained in the Barthel Scale was 17 [11] In our study, a person qualified to obtain long-term nursing care in the Barthel Scale obtained an average of 24.69 points, which was slightly more efficient in performing basic activities of life.

On the other hand, the study of Cebulak et al. cited above, conducted on the study group, showed that cognitive impairment occurred in $66.23 \%$ of the surveyed persons who were qualified to long-term nursing care, and that the average number of points obtained by those patients was 4.69 on AMTS [14]. The standard point (5.58) obtained by the tested patients, quoted in this thesis, was on the border of moderate cognitive impairment.

In foreign literature there are a lot of research projects that refer to institutional forms of long-term care, while nursing long-term care does not often appear in the professional literature.

The research by $\mathrm{Wu}$ et al. conducted in Taiwan among people at the age of 65 years and older showed, like the presented research, that the essential determinants of long-term care were: age, living alone, stroke, and cognitive impairment [15].

On the basis of studies carried out in the Netherlands, also Campen and Gameren included the age [16], as well as illnesses and disabilities, among the factors of long-term care, which is compatible with results of these research.

Chang et al. showed that among people benefitting from home medical service in Taiwan, women were predominant [17]. In our own research, women definitely prevailed among people classified for a long-term nursing care.

Olivares-Tirado et al. came to the conclusion that the most significant in long-term care is disability of elderly people [18], which is compatible with the presented research results.

The aim of the research conducted among 3133 people aged 68 years and over in Switzerland was to survey the interest of elderly people in access to the long-term care. The idea was to collect the opinions of senior people about the need for long-term care in the case of different disabilities. Another subject of these studies was the possibility to use other seniors (e.g. spouses) as informal caregivers. The surveyed people declared a definite will to benefit in future from a home longterm care rather than the institutional form [19].

In Japan there is a continually growing number of elderly people who require nursing long-term care, but the most rapidly growing group is the number of people benefitting from institutional long-term care. Kashiwagi et al., in their research conducted among elderly people living in rural areas of Japan, proved that only $8.3 \%$ of the surveyed benefitted from nursing long-term care, and they were mainly patients with respiratory and cardiovascular system disorders. In their opinion, the reason is the low income of the households and the lack of qualified staff in rural areas [20]. In our own research it was also proven that cardiovascular diseases such as a brain stroke or atherosclerosis are significant factors leading to the need for long-term nursing care.

These data suggest the need to increase the access for elderly patients to existing services of long-term home nursing care by increasing the limits, because this would allow older people with significant functional disability to remain in their natural living environment, and to support family caregivers, and thus improve the quality of their care.

\section{Conclusions}

$15.67 \%$ of rural residents over 65 years old qualified for long-term nursing care, and currently provided long-term home nursing care met the needs of slightly more than half of them. Demand for the long-term nursing care was determined by advancing age, problems with functional, emotional, and cognitive disability and was often related to women, people with lower education, and those suffering from other diseases.

\section{Conflict of interest}

The authors declare no conflict of interest.

\section{References}

1. Węgrzynowicz M. The role of primary care in the health system. State Higher Vocational School in Pila. Institute of Health - Direction of Nursing. Text Publishing. Saw, 2009.

2. Beck O, Kędziora-Kornatowska K. Social care insurance as a chance to solve the problem of care for the elderly in Poland. Medical News 2013; 82: 56-60.

3. Wilmowska-Pietruszyńska A, Putz J. The nursing care insurance as a proposal of system solutions of needs for people unable to live independently. Progress Med Sci 2009; 4: 264-267.

4. Mojsa W, Chlebicz S, Małyszko J. Characteristics of patient under long-term nursing care in 2004-2008 in Podlaskie. Gerontol Pol 2013; 21: 18-24.

5. Decree No. 87/2013/DSOZ of the President of the National Health Fund of 18 December 2013. on determining the conditions for the conclusion and implementation of 
contracts such as nursing and care services in the context of long-term care. Available at: www.nfz.gov.pl/new/ of 20.02.2014.

6. Regulation of the Minister of Health of 22 November 2013 on the guaranteed benefits in the field of nursing and care services in the context of long-term care. Acts. U. 2013. Pos. 1480.

7. Roszman A, Gaworska-Krzemińska A. The quality of nursing services, and the type of motivation in long-term care facilities. Nursing 2006; 3-4: 115-120.

8. Falenczyk K, Marzec A. Long-term care at home. In: Nursing Long-term Care. Kędziora-Kornatowska K, Muszalik M, Skolimowska E (eds). Medical Publishing PZWL, Warsaw 2010; 319-329.

9. Kulik TB. Family to the health and disease. In: Contemporary Threats to Health and Family. Kulik TB (ed). Branch Faculty of Social Sciences of the Catholic University of Lublin, Stalowa Wola 2002; 9-32.

10. Frank G, Nowak-Kapusta Z, Grzywa T. Home environment as a place for long-term nursing care of the chronically ill. Nursing 2004; 1-2: 57-59.

11. Markiewicz I, Cebulak M. The functional efficiency of patients in a long-term homenursing care. Nursing 2014; 22: 42-51.

12. Dziechciaż M, Guty E, Wojtowicz A, Schabowski J. The demand for long term care of the elderly villagers. Med News 2012; 1: 26-30.

13. Lewko J, Szymańska L, Sierakowska M, Nowodworska B, Krajewska-Kulak E. The rate of disability among the elderly and the demand for home-nursing care. Nursing 2006; 3-4: 111-114.

14. Cebulak M, Markiewicz I, Guty E. Evaluation of cognitive function for patients under the long-term nursing care. Nursing 2014; 22: 20-26.

15. Wu CY, Hu HY, Huang N, Fang YT, Chou YJ, Li CP. Determinants of long-term care services among the elderly: a population-based study in Taiwan. PLoS One 2014; 9: e89213.

16. Van Campen C, Gameren E. Eligibility for long-term care in the Netherlands: development of a decision support system. Health Soc Care Commun 2005; 13: 287-296.

17. Chang HT, Lai HY, Hwang IH, et al. Home healthcare services in Taiwan: a nationwide study among the older population. BMC Health Serv Res 2010; 10: 274.

18. Olivares-Tirado P, Tamiya N, Kashiwagi M, Kashiwagi K. Predictors of the highest long-term care expenditures in Japan. BMC Health Services Research 2011; 11: 103.

19. Santos-Eggimann B, Meylan L. Older citizens' opinions on long-term care options: a vignette survey. J Am Med Dir Assoc 2017; 18: 326-34.

20. Kashiwagi M, Tamiya N, Sato M, Yano E. Factors associated with the use of home-visit nursing services covered by the long-term care insurance in rural Japan: a cross-sectional study. BMC Geriatrics 2013; 13: 1.

\section{Address for correspondence:}

Małgorzata Dziechciaż PhD

Department of Health Sciences

Health Care Institute

State School of Higher Vocational and Economic Education

ul. Siemieńskiego 7, 37-500 Jarosław, Poland

Phone: +48503116350

E-mail: dziechciaz@vp.pl 